\title{
Outplanting performance of three provenances of Quillaja saponaria Mol. established in a Mediterranean drought-prone site and grown in different container size
}

\author{
Sergio E Espinoza ${ }^{(1)}$, \\ Marco A Yañez ${ }^{(2)}$, \\ Carlos R Magni ${ }^{(3)}$, \\ Rómulo E Santelices ${ }^{(1)}$, \\ Antonio M Cabrera ${ }^{(4)}$
}

In degraded environments with restricted seed availability, like those burned by wildfires in central Chile during 2017, the use of plant material from outside its area of origin for restoration purposes needs to be accurately investigated. We assessed the early development of three Chilean provenances of Quillaja saponaria grown in different container sizes (140 vs. $280 \mathrm{~mL})$ in the nursery and then outplanted in a common field trial at a site severely affected by fire under Mediterranean-type climate. We analyzed growth, biomass, and leaf-level physiological traits. In the nursery, there was a significant provenance by container type interaction for the biomass traits $(P<0.05)$. Seedlings from the Maule provenance cultivated in larger containers had the highest biomass, while the lowest biomass was observed for the Metropolitan provenance cultivated in small containers. Two years after outplanting, the provenance by container size interaction was significant for stomatal conductance and chlorophyll density. Seedlings from the Metropolitan provenance cultivated in larger containers exhibited a higher stomatal conductance, while those from the Maule provenance cultivated in small containers exhibited the highest chlorophyll density. Seedling height showed significant variation for provenance and container size. The tallest seedlings were those grown in larger containers from the Maule provenance; however, no differences in survival and height increment were found. Gas exchange parameters differed among provenances, the Metropolitan provenance had a low performance and the opposite was found for the Biobío and Maule provenances. This study demonstrated that different provenances of $Q$. saponaria have stable performances in a Mediterranean site, which support their use for restoration purposes outside their home area with no detrimental effects on outplanting performance.

\section{Keywords: Restoration, Quillay, Dry Site, Water Stress, Pot Size, Seed Origin}

\section{Introduction}

Quillaja saponaria Mol. is a sclerophyllous evergreen tree species widely distributed in Chile, extending longitudinally over 650 $\mathrm{km}$ from the xeric shrubland in the north to the Mediterranean and temperate forests of the south (latitudinal range from $30^{\circ}$ to $38^{\circ} \mathrm{S}-$ Cruz et al. 2013). The forest types where the species can be found have been degraded in the past by land conversion for agricultural uses, and more recently by the devastating fires that occurred in central Chile during 2017 (De la Barrera et al. 2018), which burned almost half a million hectares of land, of which $17.4 \%$ corresponds to native forests (CONAF 2017). This has raised a significant concern about the factors involved in the successful broad-scale seed-based restoration of $Q$. saponaria and other sclerophyllus species.

Banister et al. (2018) pointed out that the poor quality of nursery stock for native species is one of the main bottlenecks that constrain forest landscape restoration in Chile. Some studies have highlighted the importance of managing the stock quality on the successful early growth in restora- tion projects (Grossnickle 2012, Grossnickle \& MacDonald 2018), while other studies have focused on proper selection of the seed provenance (Bischoff et al. 2010). However, no previous investigations have examined the potential combined effects of these factors on Q. saponaria, which may provide guidance for restoration of the species.

It is well known that autochthonous seed sources are better adapted to local conditions, exhibiting higher relative fitness in their original habitat (Broadhurst et al. 2008, Broadhurst \& Boshier 2014). Performance increases as local seeds are planted near to their home site (Joshi et al. 2001). This is likely related to specific genetic adaptations of a provenance to local conditions that confers the highest fitness in their home environment when compared to non-local populations. However, the use of strict local plant material may limit the scale of restoration projects in areas severely altered (Giencke et al. 2018), due to restrictions in seed availability (Broadhurst et al. 2016). In the case of Q. saponaria, Ovalle et al. (2016a, 2016b) found high out- 
planting survival rates when using local provenances (i.e., seeds collected in a range of $40 \mathrm{~km}$ from the field test site). In a nursery experiment, Magni et al. (2018) found that different provenances of Q. saponaria exhibited a stable performance under controlled growth conditions. However, the extent to which the provenance effect contributes to the successful restoration of the species is unknown. In other sclerophyllus evergreen tree species, Gratani et al. (2003) found superior morphological and physiological responses for Quercus ilex L. provenances established close to their seed collection site.

Nursery cultural practices determine the quality of the planting stock and their functional characteristics (Palacios et al. 2009). A positive relationship between seedling quality and successful restoration has been reported for numerous tree species (VillarSalvador et al. 2012). Seedlings with a welldeveloped root system rapidly grow roots after planting (Davis \& Jacobs 2005) and tend to have higher survival than seedlings with poor developed root systems (Grossnickle 2012). This can be manipulated by the container size (Domínguez-Lerena et al. 2006). As the root system size is proportional to the container dimensions (Aphalo \& Rikala 2003), seedlings cultivated in deep containers result in higher outplanting survival than seedlings cultivated in shallow containers in Mediterranean sites, the formers developing a large root system that quickly reaches moisture in deep soil horizons (Gibbens \& Lenz 2001, Chirino et al. 2008). In a nursery experiment applying water restriction, Espinoza et al. (2017) found that survival, growth, and biomass of water-stressed Q. saponaria were higher in seedlings cultivated in large containers than in small ones ( $280 \mathrm{~mL}$ of volume). Ovalle et al. (2016a, 2016b) found a high outplanting survival (80 to $100 \%$ ) for Q. saponaria seedlings that were cultivated in $400 \mathrm{~mL}$ containers.

In this study we examined the performance of three provenances of Q. saponaria from different sites characterized by semiarid, humid, and very humid climate. Seedlings were cultured in the nursery in two container sizes and then outplanted in a site with Mediterranean-type climate. We aimed to assess the effect of stock quality and seed provenance on survival, growth, biomass, and physiological traits. The results of this study may guide the restoration decisions of $Q$. saponaria under Mediterranean-type climatic conditions.

\section{Material and methods}

\section{Plant material}

Three provenances of $Q$. saponaria located over $200 \mathrm{~km}$ from each other, and showing latitudinal-related climate differences, were studied (Tab. 1). In April 2016, dominant and co-dominant trees with welldeveloped crown, health condition, and abundant seed production were randomly selected from each provenance. Ripen fruits were collected from 10 to 20 mother trees per provenance. Seed quality was checked after collection according to ISTA standards (ISTA 2006).

\section{Nursery experiment}

The study was conducted in a nursery under ambient conditions, located at the Universidad Católica del Maule $\left(35^{\circ} 26^{\prime} \mathrm{S}, 71^{\circ}\right.$ $37^{\prime}$ W; $131 \mathrm{~m}$ a.s.l.), city of Talca, Chile. According to the De Martonne aridity index, the climate at the nursery is considered humid. Two container sizes were selected to produce planting stocks of different quality. A small container (typically used in Q. saponaria nurseries) was a tapered cylindrical pot (Termomatrices ${ }^{\circledR}$, Santiago, Chile) with cell volumes of $140 \mathrm{~mL}(15 \mathrm{~cm}$ height $x$ $4 \mathrm{~cm}$ top diameter $\times 3 \mathrm{~cm}$ bottom diameter) and 88 cavities per holding tray (cultivation density of 463 seedlings $\mathrm{m}^{-2}$ ). The large container $\left(\mathrm{BASF}^{\oplus}\right.$, Santiago, Chile) had rectangular cells of $280 \mathrm{~mL}(14 \mathrm{~cm}$ height $\times 5.5 \mathrm{~cm}$ top diameter $\times 4.5 \mathrm{~cm}$ bottom diameter) and each tray was made of 60 cells (cultivation density of 254 seedlings $\mathrm{m}^{-2}$ ). The substrate consisted of a mixture of composted bark of Pinus radiata D. Don and perlite $(7: 3 \mathrm{v} / \mathrm{v})$, combined with the slow release fertilizer Basacote $9 \mathrm{M}^{\oplus}\left(16 \% \mathrm{~N}, 8 \% \mathrm{P}_{2} \mathrm{O}_{5}, 12 \% \mathrm{~K}_{2} \mathrm{O}, 12 \% \mathrm{SO}_{3}, 2 \%\right.$ $\mathrm{MgO}, 0.02 \% \mathrm{~B}, 0.05 \% \mathrm{Cu}, 4 \% \mathrm{Fe}$ and $0.06 \%$ $\mathrm{Mn}$ - Compo Expert GmbH, Münster, Germany) at a dose of $4 \mathrm{~g} \mathrm{~L}^{-1}$. Seeds were sown on October 2016 and cultivated by 10 months. Seedlings were watered regularly at container capacity with an automatic irrigation system. Temperature and relative humidity averaged $19{ }^{\circ} \mathrm{C}$ and $70 \%$, respectively for the cultivation period. Seedlings were arranged in a randomized complete block design, with a border row of extra seedlings around each tray to minimize edge effects. The total number of seedlings evaluated were 540 (i.e., 2 container sizes $\times 3$ provenances $\times 3$ replicates $\times 30$ seedlings per replicate).

At field planting (August 2017), height $(H)$ and root collar diameter (D) were measured for all the provenances in all seedlings using a metric tape and a digital caliper, respectively. Average $\mathrm{H}$ and $\mathrm{D}$ were $22.7 \pm 0.8 \mathrm{~cm}$ and $3.5 \pm 0.07 \mathrm{~mm}$, respectively. In addition, a subsample of five seedlings per treatment and replication (i.e., 90 seedlings) were used to determine biomass components. Seedlings were harvested from the containers and oven-dried at $65{ }^{\circ} \mathrm{C}$ for $48 \mathrm{~h}$. Roots, leaves, and stems were separately weighed $( \pm 0.01 \mathrm{~g})$, giving the root dry weight (RDW), the leaves dry weight (LDW), the stem dry weight (SDW), and the total dry weight (TDW). The root to shoot ratio was derived as RSR = RDW/ (SDW+LDW). According to Niklas \& Enquist (2002) and Grossnickle (2012), the root: shoot ratio reflects the balance between water acquisition of the root system (roots component) and water losses of the transpiring shoot system (leaves plus stems).

\section{Field trial}

A field trial was established in August 2017 in the locality Nirivilo $\left(35^{\circ} 34^{\prime} \mathrm{S}, 72^{\circ} 06^{\prime}\right.$ W; $254 \mathrm{~m}$ a.s.l), San Javier, central Chile, on a flat site property of the Universidad de Chile. The site has a Mediterranean-type climate with no summer rainfall, $675 \mathrm{~mm}$ of rainfall from June to August, $396 \mathrm{~mm}$ of evaporation from December to February, and a maximum temperature of $25^{\circ} \mathrm{C}$ during January. According to the De Martonne aridity index, the climate at the field test site is considered humid. The soil is neutral $(6.1 \mathrm{pH})$, sandy clay ( $47 \%$ sand, $17 \%$ lime, $36 \%$ clay), with low electrical conductivity ( 0.03 dS $\mathrm{m}^{-1}$ ) and $1.5 \%$ organic matter content. The available soil nutrient composition was $4 \mathrm{mg} \mathrm{kg}^{-1} \mathrm{~N}, 8 \mathrm{mg} \mathrm{kg}^{-1} \mathrm{P}$, and $168 \mathrm{mg} \mathrm{kg}^{-1} \mathrm{~K}$.

The site previously supported a 6-year-old $P$. radiata plantation and introduced pasture grasses that were both severely damaged by the fires that occurred during January 2017 in central Chile. The field experiment followed a randomized complete block design with two levels of container

Tab. 1 - Location and climatic parameters for the nursery and field experiments, and the seed collection sites of the three provenances of Q. saponaria under study. (MAP): mean annual precipitation (mm); (MAT): mean annual temperature $\left({ }^{\circ} \mathrm{C}\right)$. The De Martonne aridity index was estimated as MAP/(MAT + 10).

\begin{tabular}{|c|c|c|c|c|c|c|c|c|}
\hline Experiment & Provenance & Location & $\begin{array}{l}\text { Latitude } \\
\text { S }\end{array}$ & $\begin{array}{l}\text { Longitude } \\
\text { W }\end{array}$ & MAP & MAT & $\begin{array}{l}\text { De Martonne } \\
\text { aridity index }\end{array}$ & Climate type \\
\hline \multirow[t]{3}{*}{ Seed collection } & Metropolitan & Interior & $33^{\circ} 32^{\prime}$ & $71^{\circ} 11^{\prime}$ & 436 & 16.7 & 16.3 & Semiarid \\
\hline & Maule & Coastal & $35^{\circ} 14^{\prime}$ & $72^{\circ} 18^{\prime}$ & 839 & 13.5 & 35.3 & Humid \\
\hline & Biobío & Interior & $37^{\circ} 09^{\prime}$ & $72^{\circ} 32^{\prime}$ & 1122 & 13.4 & 47.9 & Very humid \\
\hline Nursery experiment & Maule & Interior & $35^{\circ} 26^{\prime}$ & $71^{\circ} 37^{\prime}$ & 757 & 14.6 & 30.7 & Humid \\
\hline Field test site & Maule & Interior & $35^{\circ} 34^{\prime}$ & $72^{\circ} 06^{\prime}$ & 984 & 13.4 & 42.0 & Humid \\
\hline
\end{tabular}


size, three provenances, and 3 replications of 7-seedlings per row (i.e., 126 seedlings in total). The site was fenced to avoid herbivore damage and seedlings were hand planted at a spacing of $1 \times 1 \mathrm{~m}$. No fertilizer was added to the planting hole. During the first summer season after outplanting, seedlings were watered with $4 \mathrm{~L}_{\text {plant }}{ }^{-1}$ month $^{-1}$ from December 2017 to March 2018 in order to mitigate the negative effect of water stress on early performance. Furthermore, seedlings were protected with tree shelters (Surpack S.A., Lima, Peru) made up of green, polyethylene tubes ( 80 $\mathrm{cm}$ tall $\times 20 \mathrm{~cm}$ wide). Light transmittance into the shelters was measured with a LI250 quantum sensor (LI-COR Inc., Lincoln, NE, USA) during January 2019, and it was $15 \%$ of full sunlight, i.e., photosynthetic active radiation (PAR) of $300 \mathrm{mmol} \mathrm{m}^{2} \mathrm{~s}^{1}$. Additionally, soil temperature, and water content at $10-\mathrm{cm}$ depth were measured once a month during the spring-summer of the first growing season (from September 2017 to March 2018) in three points per replicate by using a soil temperature/moisture sensor $\left(\mathrm{CS}^{\circledR}{ }^{\oplus}\right.$ dielectric probe, Decagon Devices Inc., Pullman, WA, USA). Average values are shown in Fig. 1.

\section{Morphological and leaf-level physiological measurements at field test site}

At the end of the second growing season (May 2019), H, D, and survival (as a categorical trait: 1 = alive; $0=$ dead) were measured for each seedling. The $\mathrm{H}$ increment was calculated as the difference in growth between May 2019 and August 2017. Additionally, the last week of January 2019 we measured light-saturated photosynthetic rate $\left(A_{\text {sat }}, \mu \mathrm{mol} \mathrm{CO} \mathrm{Cm}^{-2} \mathrm{~s}^{-1}\right)$, transpiration $(\mathrm{E}$,

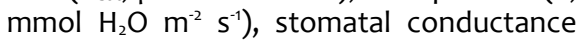
$\left(\mathrm{g}_{\mathrm{s}}, \mathrm{mol} \mathrm{H}_{2} \mathrm{O} \mathrm{m}^{-2} \mathrm{~s}^{-1}\right)$, and the derived intrinsic water use efficiency $\left(W U E_{\text {int }}=A_{\text {sat }} / g_{s}\right)$, in a fully-developed leaf obtained on the upper third of the seedlings ( 5 seedlings per experimental unit). These measurements were taken between 11:00 and 15:00 (local time) using a portable photosynthesis system (Li-6400XT ${ }^{\circledR}$, LI-COR Inc., Lincoln, NE, USA) provided with a light source (Li-6400O2B). In order to avoid sudden changes in leaf light level we opened the shelters and quickly put a leaf into the chamber. Temperature, air $\mathrm{CO}_{2}$ concentration, and light source were set at ambient conditions to $25^{\circ} \mathrm{C}, 400 \mathrm{ppm}$, and $1800 \mathrm{mmol} \mathrm{m}^{2} \mathrm{~s}^{1}$, respectively. Chlorophyll density measurements (i.e., SPAD values) were also obtained using a chlorophyll meter (Minolta SPAD-502 ${ }^{\circledast}$ meter, Minolta Camera CO., Osaka, Japan) on three individual leaves per tree. The SPAD-502 meter provides indirect reliable estimates of relative densities of leaf chlorophyll (Richardson et al. 2002).

\section{Data analysis}

All variables were subjected to an analysis of variance, except survival which was tested using a Chi-square test. The statisti-

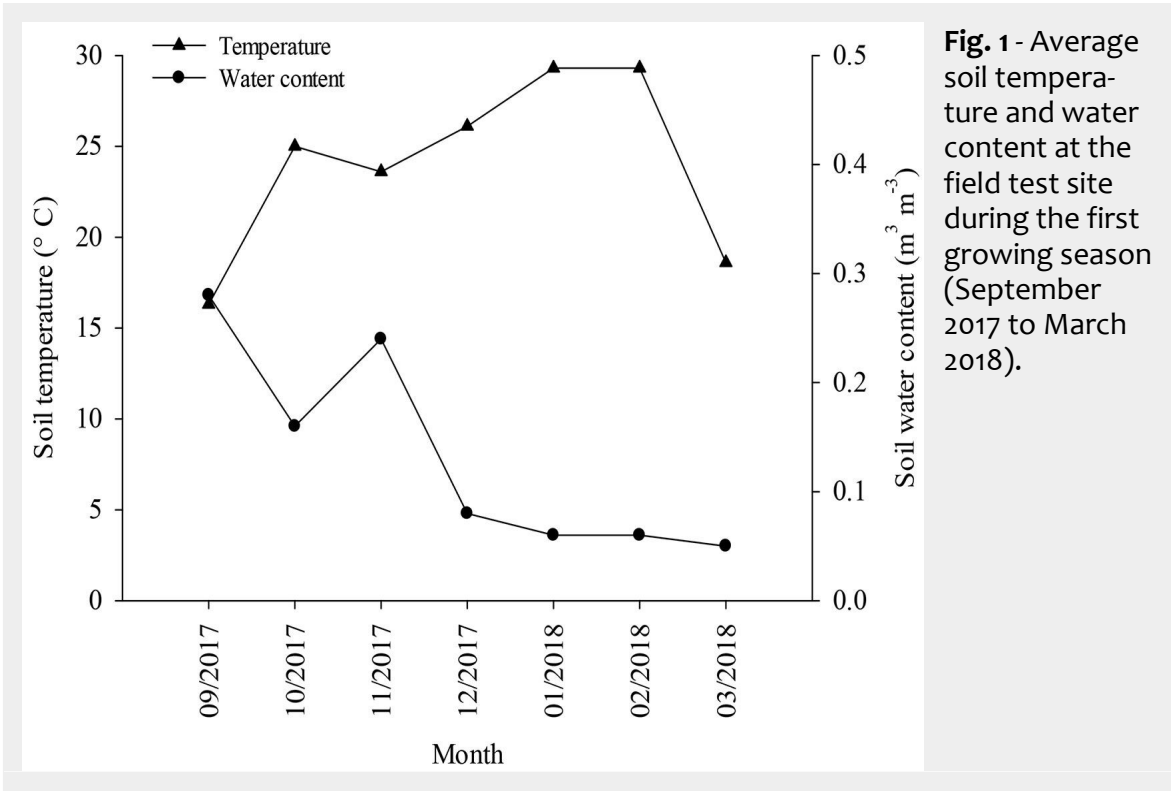

cal model applied to both the nursery and field experiment was (eqn. 1):

$$
Y_{i j k l}=\mu+B_{i}+P_{j}+C_{k}+P \times C_{j k}+e_{i j k l}
$$

where $Y_{i j k l}$ is the measurement, $\mu$ is the overall mean, $B_{i}$ is the fixed effect of the $i^{\text {th }}$ block, $P_{j}$ is the fixed effect of the $j^{\text {th }}$ provenance $(j=$ Metropolitan, Maule, and Biobío provenances), $C_{k}$ is the fixed effect of the $k^{\text {th }}$ container size ( $k=140$ vs. $\left.280 \mathrm{~mL}\right), P \times C_{j k}$ is the interaction between provenance and container size, and $e_{\text {ijkl }}$ is the experimental random error. Mean comparisons were made by the Tukey multiple range test $(a=$ 0.05). Additionally, the relationship between seedlings initial characteristics at the nursery stage with field performance

was investigated separately for each provenance through regression analysis. All the statistical analyses were performed with the software SPSS ${ }^{\circledast}$ ver. 18.0 (SPSS Inc., Chicago, IL, USA).

\section{Results}

\section{Growth and biomass at nursery}

At the end of the nursery phase, the analysis on the main effects showed that the Maule and Metropolitan provenances had the highest and lowest values for $\mathrm{D}$ and $\mathrm{H}$ (Fig. 2A, B). Similarly, larger containers produced larger seedlings $(P<0.05-$ Fig. $2 C$, $D)$. Interestingly, $\mathrm{H}$ was 2 -fold higher in the larger containers. The effect of the provenance by container size interaction was sig-
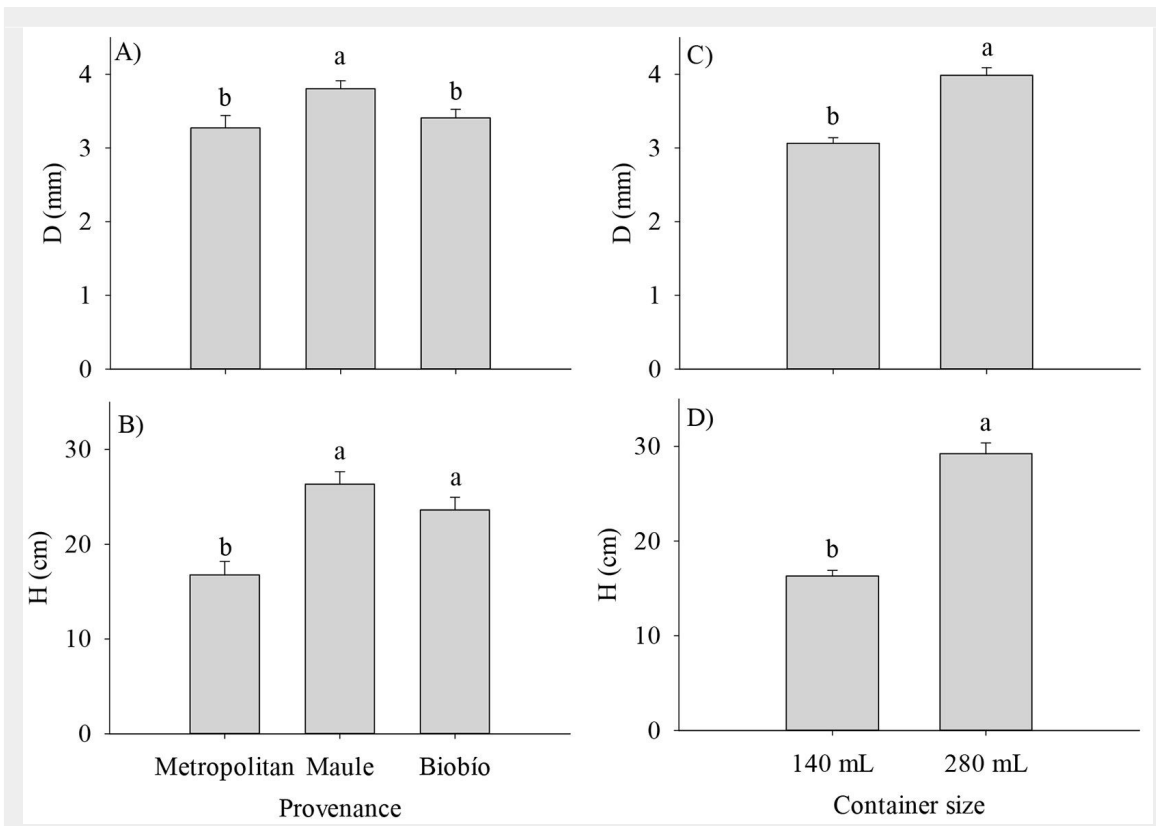

Fig. 2 - Growth traits of Q. saponaria seedlings at the end of the nursery stage. (D): root collar diameter; $(H)$ : height. Different letters indicate significant $(p<0.05)$ differences among means. The error bars indicate the standard error. 

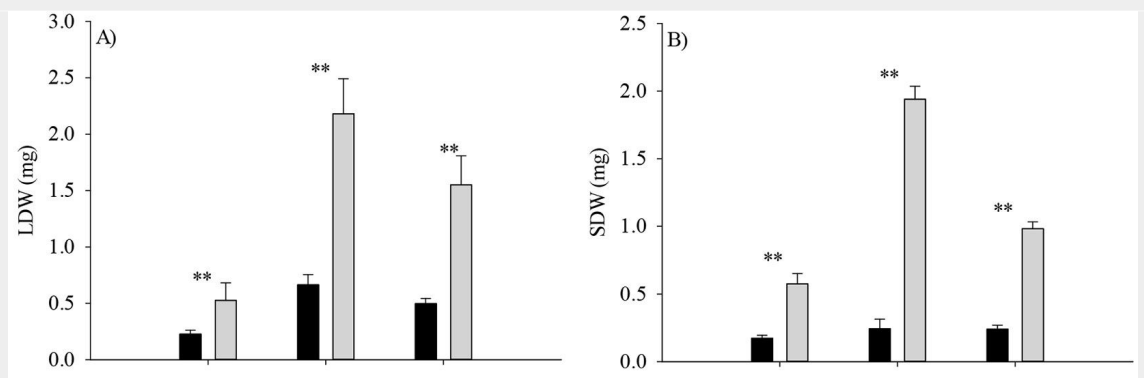

Tab. 2 - Significance of the main factors and interactions on growth and biomass traits of Q. saponaria seedlings as derived from the analysis of variance (ANOVA). (P): provenance; (C): container size; (D): root collar diameter; (H): height; (RDW): roots dry weight; (LDW): leaves dry weight; (SDW): shoot dry weight; (TDW): total dry weight; (RSR): root to shoot ratio.
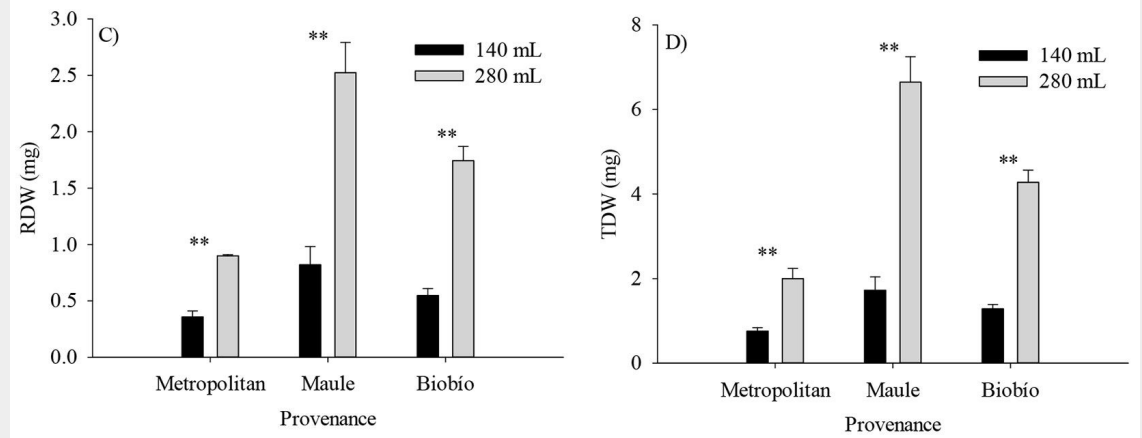

Fig. 3 - Effect of the provenance by container size interaction on biomass traits of Q. saponaria seedlings at the end of the nursery stage. (LDW): leaves dry weight; (SDW): shoot dry weight; (RDW): roots dry weight; (TDW): total dry weight; $(* *)$ : $p<0.01 ;\left(^{*}\right)$ : $\mathrm{p}<0.05$. The error bars indicate the standard error.

\begin{tabular}{lrrr}
\hline Trait & $\mathbf{P}$ & $\mathbf{C}$ & $\mathbf{P} \times \mathbf{C}$ \\
\hline D & 0.02 & $<0.01$ & 0.13 \\
H & $<0.01$ & $<0.01$ & 0.30 \\
RDW & $<0.01$ & $<0.01$ & 0.02 \\
\hline LDW & $<0.01$ & $<0.01$ & $<0.01$ \\
SDW & $<0.01$ & $<0.01$ & 0.01 \\
\hline TDW & $<0.01$ & $<0.01$ & 0.00 \\
\hline RSR & 0.38 & 0.16 & 0.38 \\
\hline
\end{tabular}

nificant for most of the biomass components but not for H, D, and RSR (Tab. 2). The highest responses in TDW, RDW, SDW, and LDW to the container size of the Maule provenance relative to the Metropolitan provenance explained the provenance by container size interaction (Fig. 3).
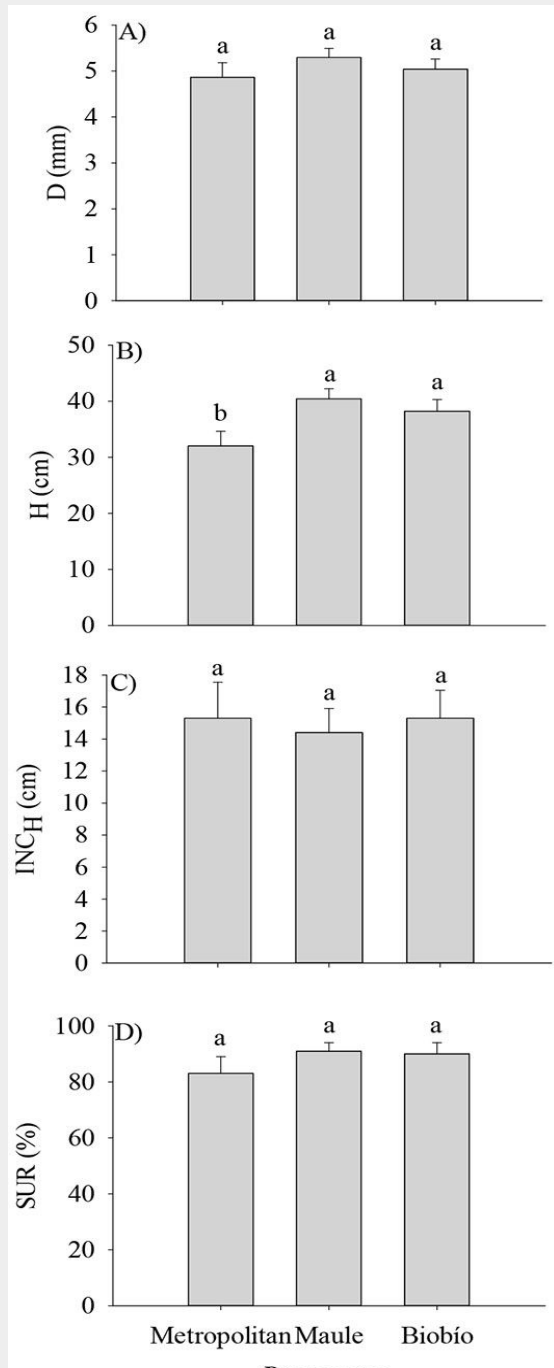

Provenance
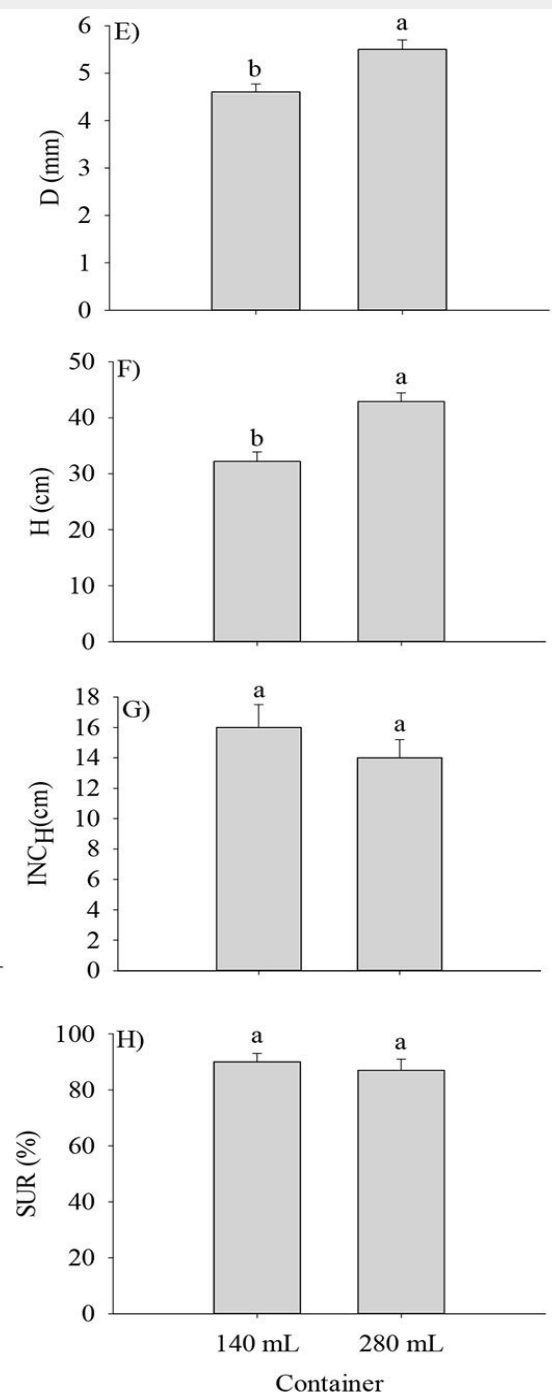

Fig. 4 - Growth and survival of Q. saponaria seedlings after two growing seasons in the field test site. (D): root collar diameter; $(H)$ : height; $\left(I N C_{H}\right)$ : increment for height; (SUR): survival. Different letters indicate significant $(p<0.05)$ differences among means. The error bars indicate the standard error. 
Fig. 5 - Gas exchange traits of Q. saponaria seedlings after two growing seasons at the field test site, according to the provenance (panels A, B, C) and container size (panels D, $E, F) .\left(A_{\text {sat }}\right)$ : light-saturated photosynthetic rate; $(E)$ : transpiration; $\left(W U E_{\text {int }}\right)$ : intrinsic water use efficiency. Different letters indicate significant $(p<0.05)$ differences among means. The error bars indicate the standard error.
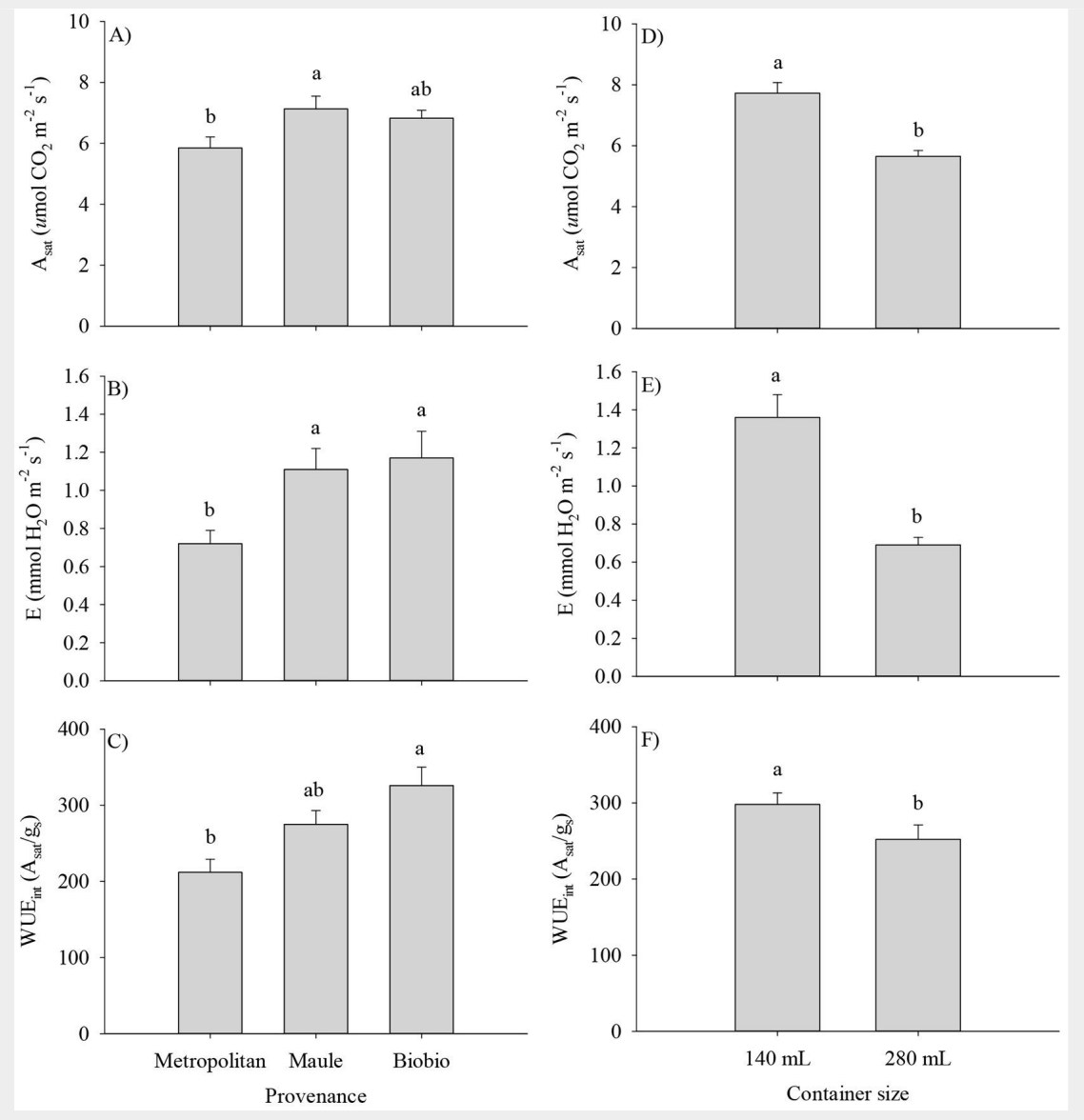

Survival, growth, and leaf-level physiology at field- test site

Two growing seasons after outplanting, the analyses of main effects revealed that $\mathrm{D}$ and $\mathrm{H}$ were higher in large containers, and $\mathrm{H}$ was superior in the Maule and Biobío provenances (Fig. 4). There were no effects of the provenance, the container size, or their interaction on $\mathrm{D}$, survival, and $\mathrm{H}$ increment ( $P>0.05$ - Fig. 4A, C, D, G, H).

For gas exchange traits, means for $A_{\text {sat }}, E$, and $\mathrm{WUE}_{\text {int }}$ were lower for the Metropolitan provenance (Fig. 5A, B, C), and in the case of the container size, seedlings cultivated in small containers exhibited the

Tab. 3 - Significance of main factors and interactions on gas exchange traits of Q. saponaria seedlings derived from the analysis of variance (ANOVA). (P): provenance; $(C)$ : container size; $\left(A_{\text {sat }}\right)$ : lightsaturated photosynthetic rate (umol $\left.\mathrm{CO}_{2} \mathrm{~m}^{-2} \mathrm{~s}^{-1}\right)$; (E): transpiration ( $\mathrm{mmol} \mathrm{H}_{2} \mathrm{O}$ $\left.\mathrm{m}^{-2} \mathrm{~s}^{-1}\right)$; $\left(\mathrm{g}_{\mathrm{s}}\right)$ : stomatal conductance ( $\mathrm{mol}$ $\left.\mathrm{H}_{2} \mathrm{O} \mathrm{m}^{-2} \mathrm{~s}^{-1}\right)$; (WUE int): Intrinsic water use efficiency $\left(A_{\text {sat }} / g_{s}\right)$; (SPAD value): chlorophyll density.

\begin{tabular}{lrrr}
\hline Trait & $\mathbf{P}$ & $\mathbf{C}$ & $\mathbf{P} \times \mathbf{C}$ \\
\hline $\mathrm{A}_{\text {sat }}$ & $<0.01$ & $<0.01$ & 0.64 \\
$\mathrm{~g}_{\mathrm{s}}$ & 0.20 & 0.52 & $<0.01$ \\
$\mathrm{E}$ & $<0.01$ & $<0.01$ & 0.13 \\
WUE $_{\text {int }}$ & $<0.01$ & 0.03 & 0.06 \\
\hline SPAD value & 0.56 & 0.40 & 0.01 \\
\hline
\end{tabular}

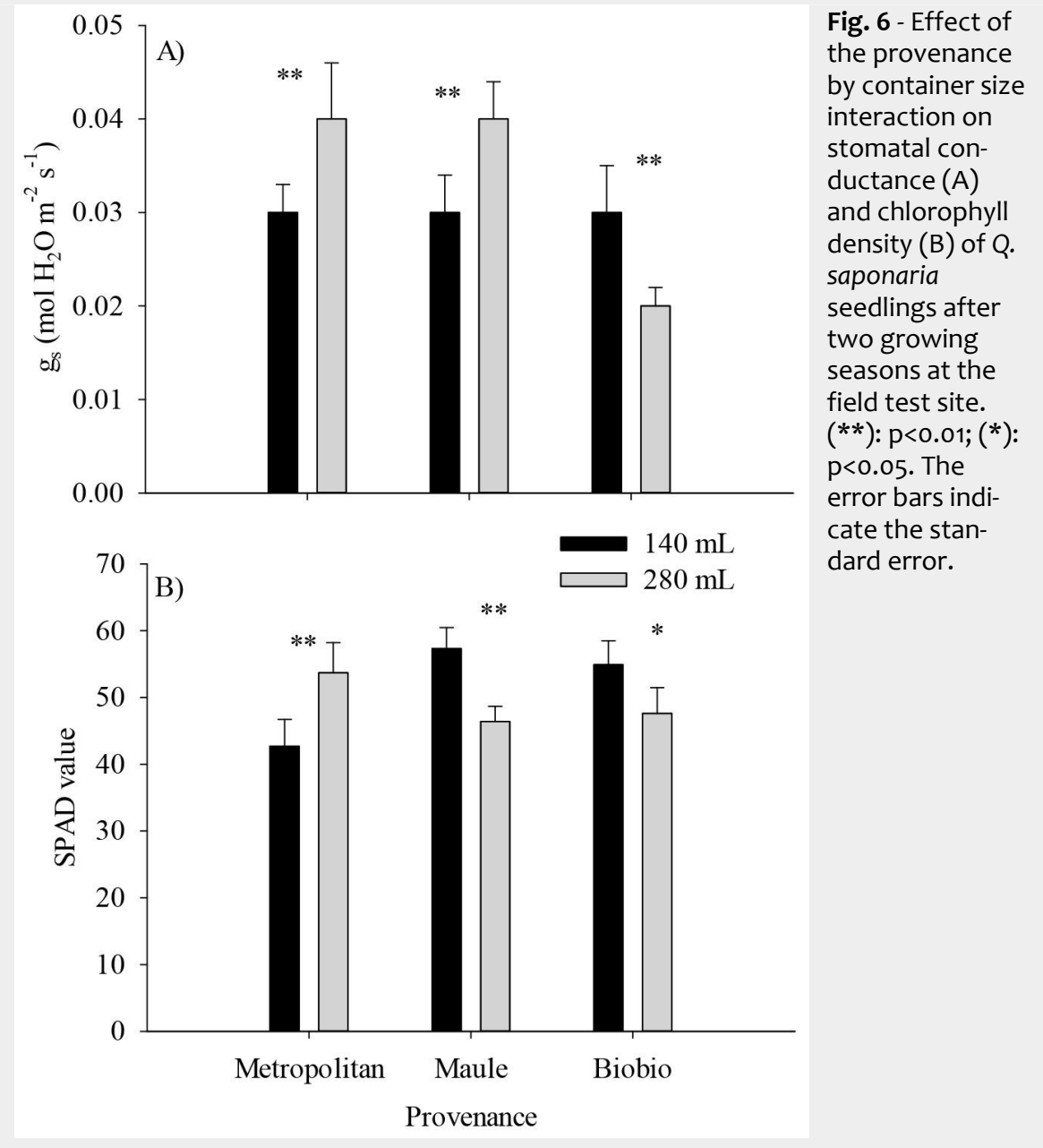


Tab. 4 - Pearson's correlation coefficients between the initial quality characteristics of seedlings and field performance two years after planting. (D): root collar diameter; (H): height; (RDW): roots dry weight; (LDW): leaves dry weight; (SDW): shoot dry weight; (TDW): total dry weight; (RSR): root to shoot ratio; (SUR): survival; $\left(\mathrm{INC}_{\mathrm{H}}\right.$ ): increment for height; $(* *): p<0.01 ;(*): p<0.05$.

\begin{tabular}{llcccc}
\hline \multirow{2}{*}{ Provenance } & Seedling traits & \multicolumn{4}{c}{ Seedling traits at field } \\
\cline { 3 - 5 } & at nursery & $\mathrm{D}$ & $\mathrm{H}$ & SUR & $\mathrm{INC}_{\mathrm{H}}$ \\
\hline \multirow{2}{*}{ Metropolitan } & $\mathrm{D}$ & $0.88^{* *}$ & $0.70^{* *}$ & 0.47 & 0.12 \\
& $\mathrm{H}$ & $0.69^{* *}$ & $0.94^{* *}$ & 0.29 & 0.09 \\
\multirow{2}{*}{ Maule } & $\mathrm{D}$ & $0.74^{* *}$ & $0.54^{* *}$ & 0.09 & 0.02 \\
& $\mathrm{H}$ & $0.46^{* *}$ & $0.92^{* *}$ & 0.07 & 0.09 \\
\multirow{2}{*}{ Biobío } & $\mathrm{D}$ & $0.73^{* *}$ & $0.60^{* *}$ & $0.78^{*}$ & 0.12 \\
& $\mathrm{H}$ & $0.58^{* *}$ & $0.89^{* *}$ & $0.86^{*}$ & 0.09 \\
\hline
\end{tabular}

highest $A_{\text {sat }}, E$ and $W E_{\text {int }}$ (Fig. 5D, E, F). There was a significant effect of the provenance by container size interaction on $g_{\text {s }}$ and chlorophyll density (i.e., SPAD value Tab. 3). Provenances differed in $g_{s}$ only in the larger containers, with the Maule and Metropolitan provenances doubling the values of the Biobío provenance (Fig. 6A). Unlike, the chlorophyll density in the Maule and Biobío provenances was higher in small but lower in the large containers when compared with the Metropolitan provenance (Fig. 6B).

Relationship between nursery stock and field performance

As expected, when comparing the correlations of $\mathrm{D}$ and $\mathrm{H}$ between the nursery and field test site, these were high and positive. However, with the exception of Biobío provenance, the relationship between seedlings characteristics measured at the nursery with survival and height increments in the field, showed low and poor correlations (Tab. 4).

\section{Discussion}

\section{Growth and biomass at nursery level}

The three provenances under study showed differences in growth traits at the nursery level, but some of such differences tend to disappear in the field. Seedlings from the Maule provenance exhibited superior $\mathrm{H}$, aboveground (LDW, and SDW) and belowground (RDW) biomass. This superior performances may be probably related to the similarity of climatic conditions between seed collection site and nursery. Indeed, seeds were collected at just 12 minutes of latitude away from the nursery and both environments exhibited similar aridity index. On the contrary, the Metropolitan provenance seedlings, whose seeds were collected at latitude $33^{\circ}$ and cultivated in a nursery located at latitude $35^{\circ}$, had the lowest $\mathrm{H}$ and biomass. In other sclerophyllous species, Bonito et al. (2011) found the lowest seedling height for a provenance of $Q$. ilex whose seeds were collected in the north of Italy (latitude $45^{\circ} \mathrm{N}$ ) and cultivated in a nursery located in the centre of the country (latitude $41^{\circ} \mathrm{N}$ ). The authors at- tributed their results to the low relative growth rate of this provenance. The effect of the container size on biomass components of all of the provenances corroborates that small containers imposes physical restrictions on root growth (Aphalo \& Rikala 2003). RDW was the lowest for the Metropolitan provenance seedlings cultivated in small containers. This provenance also exhibited the lowest biomass components, but this was especially true for small containers which had half of the volume in comparison to the large containers. Poorter et al. (2012) pointed out that seedlings increase in weight using larger pots, i.e., the larger the container the larger the seedling that can be produced. In general, larger containers provide more water per gram of plant, and this holds especially for the Maule provenance cultivated in larger containers. In a nursery study with Q. saponaria, Espinoza et al. (2017) reported a superior morphological and physiological performance for seedlings cultivated in large containers $(280 \mathrm{~mL})$. Similarly, Tsakaldimi et al. (2005) in a nursery experiment with Q. ilex and Quercus coccifera L. found that seedlings exhibited superior diameter and root biomass when cultivated in the rigid containers of higher volume.

\section{Survival and growth at field- test site}

Our results showed that survival (90\% on average) was not affected by provenance and container, though there was not enough evidence supporting the effect of the initial seedling size on the outplanting growth and survival in all provenances. Similarly, in the sclerophyllous species Q. ilex and Q. coccifera, Tsakaldimi et al. (2013) and Del Campo et al. (2010) found no significant correlations between field survival and seedling traits at nursery. This can be attributed to the fact that in water-limited environments (such as our study site) it is not clear which seedling attributes determines establishment success (Trubat et al. 2010). Interestingly, seedlings from the Metropolitan provenance exhibited a high survival after outplanting, despite their low $\mathrm{H}$ and biomass at the nursery, and the environmental differences between their site of origin and the field test site. This prove- nance is likely to benefit from the wetter conditions experienced in the field test site. The deep and extensive root system of Q. saponaria (Giliberto \& Estay 1978) allows the species to tolerate water potentials up to $-5.6 \mathrm{MPa}$ in sites with Mediterranean-type climate (Ovalle et al. 2016a). This could have avoided the competition for water with herbaceous plants in the top soil horizons (Grossnickle 2005). Padilla \& Pugnaire (2007) found that rooting depth had a strong positive effect on seedling development in arid environments. On the other hand, tree shelter protection used in the field trial may have also accounted for the high and consistent survival among provenances. Shelters are known to increase humidity, decrease excessive irradiance, and buffer extreme temperatures (Padilla et al. 2011). Padilla et al. (2011) and Rey-Benayas (1998) found that shading exerted a positive effect on Q. ilex and Q. coccifera survival in arid landscapes.

At the nursery level, we observed a clear effect of the provenance on seedling growth; however, contrary to our expectations, there was no clear evidence of home site advantage for outplanting survival and increment for $\mathrm{H}$ in the Maule provenance. Indeed, theory predicts that local genotypes should perform better than non-local genotypes when grown at their site of origin (Van Der Mijnsbrugge et al. 2010), but there is also evidence suggesting that this is less frequent than commonly assumed (Leimu \& Fischer 2008). In our study the Biobío provenance, which was planted at a lower latitude as compared to the seed collection site ( $37^{\circ} 09^{\prime}$ vs. $35^{\circ} 34^{\prime}$, respectively), exhibited similar survival to the Maule provenance, whose seed was collected near the field test site $\left(35^{\circ} 14^{\prime}\right)$. Ovalle et al. (2016a, 2016b) by using a very strict local provenancing in Q. saponaria (i.e., the field test site was located close to the seed collection site), found high levels of outplanting survival; however, these authors evaluated only one provenance and attributed their results to the nursery fertilization, watering, and control of herbivory in the field test site. It was expected that the translocation of Metropolitan provenance could result in poor adaptation; however, survival and height increment were homogeneous, despite that seedlings from the Metropolitan provenance were the shortest at the nursery. This reaffirms the contention of Broadhurst \& Boshier (2014) who indicated that "local" should not be based on administrative or geographic boundaries, but on an adaptive scale. Accordingly, our results suggest that plant material of Q. saponaria could be conveniently used for restoration purposes outside its area of origin with no negative effects on seedling survival. This could overcome the scarce availiability of seeds from local sources for the restoration of areas severely burned by fire in central Chile in 2017 (De la Barrera et al. 2018). However, the possible use of non-local seed sources 
for other Mediterranean sclerophyllous species in highly disturbed ecosystems should be tested in advance through the implementation of common garden and reciprocal transplant experiments.

\section{Leaf-level physiology at field test site}

The photosynthetic rate of $Q$. saponaria seedlings in this study varied from 5.8 to 7.1 $\mu \mathrm{mol} \mathrm{CO}_{2} \mathrm{~m}^{-2} \mathrm{~s}^{-1}$. Likewise, Ovalle et al. (2016b) found $A_{\text {sat }}$ values of $7.2 \mu \mathrm{mol} \mathrm{CO}$ $\mathrm{m}^{-2} \mathrm{~s}^{-1}$ for seedlings of Q. saponaria planted in a site with Mediterranean-type climate with precipitation of $300 \mathrm{~mm}^{\text {year }}{ }^{-1}$. They also found high increments in height after one season in the field (average height of $54.7 \mathrm{~cm}$ ) using short seedlings at the plant ing date (average height of 6-8 cm). How ever, seedlings were cultivated in $400 \mathrm{~mL}$ containers and controlled-release nitrogen fertilization was applied at the planting hole. Moreover, they collected the seeds a few minutes of latitude away from the field test site. Thus, container size, fertilization, and local seed provenance should have a strong effect in their positive results.

Plasticity for physiological parameters has been reported to be greater than that for morphological traits (Valladares et al. 2002a, 2002b, Niinemets \& Valladares 2004). Unlike outplanting survival, our study showed that $Q$. saponaria exhibits differences among provenances in gas exchange parameters. This result agrees with several reports indicating that patterns of leaf-level gas exchange correlate with the climate of the seed origin, particularly with rainfall. Abrams et al. (1990) and Seiler \& Johnson (1988) observed that Fraxinus pennsylvanica Marsh and Pinus taeda $L$. seedlings from xeric sources had lower rates of photosynthesis, leaf conductance, and transpiration than seedlings from mesic sources. This agrees with our study as we found lower values for $A_{\text {sat }}, E$, and $W_{U} E_{\text {int }}$ in Metropolitan provenance, which also had the lowest De Martonne aridity index, thus suggesting local physiological adaptations. As nitrogen plays an important role in photosynthesis, the low chlorophyll density (which reflects the nitrogen status) observed in the Metropolitan provenance cultivated in small containers could imply a low light capture capacity of this provenance, but this hypothesis needs to be tested by further research.

The superior WUE $\mathrm{W}_{\text {int }}$ of Biobío and Maule provenances compared to the Metropolitan provenance may be attributed to an increase of $A_{s a t}$ rather than a reduction in $g_{s}$. Both provenances showed superior levels of $A_{\text {sat }}$ compared with Metropolitan provenance, while stomatal conductance was similar across all provenances, even though a small decrease was only observed in the Biobío seedlings cultivated in large containers. As larger seedlings generally display a greater photosynthetic active surface in terms of leaf biomass (Luis et al. 2009), it seems that the better planting stock of Maule and Biobío provenances (i.e., high $\mathrm{H}$ and LDW in the nursery) was also reflected in a better photosynthesis in the field.

\section{Conclusions}

Testing seedlings from different provenances of Q. saponaria in a common field experiment revealed that plant material of this species could be used for restoration purposes outside its area of origin with no detrimental effects on seedling survival after outplanting. Provenance and container size had significant effects on seedling traits at the nursery stage, but these effects tend to disappear at the outplanting site. This suggests that the site conditions at the field test site (i.e., a degraded ecosystem with presence of summer drought and severe fires) are important drivers in affecting seedling performance; however, this hypothesis needs further research though reciprocal transplant experiments.

\section{Acknowledgments}

Seeds for the nursery experiment and field trial were kindly provided by the Centro de Semillas y Árboles Forestales (CESAF) from the Universidad de Chile. We are indebted with those who provided support in the field and laboratory work, especially Cristian Hernández, Gustavo Hernández, Francisco Méndez, Suraj Vaswani, Betsabé Abarca, and Nicole Toro from the Universidad de Chile, and César Gallardo and Pilar Ríos, from the Universidad Católica del Maule. SEE was supported by the Comisión Nacional de Ciencia y Tecnología (CONICYT grant no. 79150013), AMC was supported by a postdoctoral fellowship from the Universidad Católica del Maule.

\section{References}

Abrams MD, Kubiske ME, Steiner KC (1990). Drought adaptations and responses in five genotypes of Fraxinus pennsylvanica Marsh.: photosynthesis, water relations and leaf morphology. Tree Physiology 6: 305-315. - doi: 10.1093/treephys/6.3.305

Aphalo P, Rikala R (2003). Field performance of silver-birch planting-stock grown at different spacing and in containers of different volume. New Forests 25: 93-108. - doi: 10.1023/A:1022618 810937

Banister JR, Vargas-Gaete R, Ovalle JF, Acevedo A, Fuentes-Ramirez A, Donoso PJ, Promis A, Smith-Ramírez C (2018). Major bottlenecks for the restoration of natural forests in Chile. Restoration Ecology 26 (6): 1039-1044. - doi: 10.1111 /rec.12880

Bischoff A, Steinger T, Müller-Schärer H (2010). The importance of plant provenance and genotypic diversity of seed material used for ecological restoration. Restoration Ecology 18: 338348. - doi: 10.1111/j.1526-100X.2008.00454.x

Bonito A, Varone L, Gratani L (2011). Relationship between acorn size and seedling morphological and physiological traits of Quercus ilex L. from different climates. Photosynthetica 49 (1): 75-86. - doi: 10.1007/s11099-011-0014-2

Broadhurst LM, Lowe A, Coates DJ, Cunningham SA, McDonald M, Vesk PA, Yates C (2008). Seed supply for broadscale restoration: maximizing evolutionary potential. Evolutionary Applications 1: 587-597. - doi: 10.1111/j.1752-4571.2008.00 045.x

Broadhurst L, Boshier DH (2014). Seed provenance for restoration and management: conserving evolutionary potential and utility. In: "Genetic Considerations in Ecosystem Restoration using Native Tree Species" (Bozzano $M$, Jalonen R, Thomas E, Boshier, D, Gallo L, Cavers S, Bordács S, Smith P, Loo J eds). FAO, Rome, Italy, pp. 27-33.

Broadhurst LM, Jones TA, Smith FS, Guja L (2016). Maximizing seed resources for restoration in an uncertain future. Bioscience 66: 7379. - doi: 10.1093/biosci/biv155

Chirino E, Vilagrosa A, Hernández El, Matos A, Vallejo VR (2008). Effects of a deep container on morpho-functional characteristics and root colonization in Quercus suber L. seedlings for reforestation in Mediterranean climate. Forest Ecology and Management 256: 779-785. - doi: 10.1016/j.foreco.2008.05.035

CONAF (2017). Análisis de la afectación y severidad de los incendios forestales ocurridos en enero y febrero de 2017 sobre los usos de suelo y los ecosistemas naturales presentes entre las regiones de Coquimbo y Los Ríos de Chile [Analyses of effects and severity of the 2017 fires on land use and nature ecosystems in the Coquimbo and Los Ríos Chilean administrative regions]. Informe Técnico, Corporación $\mathrm{Na}$ cional Forestal, Santiago, Chile, pp. 51. [in Spanish]

Cruz P, Schulz C, Honeyman P, Cabello A (2013). Quillaja saponaria Mol. Quillay Familia: Quillajaceae. In: "Las Especies Arbóreas de los Bosques Templados de Chile y Argentina" [The Woody Species of the Temperate Forests of Chile and Argentina] (Donoso C ed). Autoecología. Marisa Cuneo Ediciones, Valdivia, Chile, pp. 545-555. [in Spanish]

Davis AS, Jacobs DF (2005). Quantifying root system quality of nursery seedlings and relationship to outplanting performance. New Forests 30: 295-311. - doi: 10.1007/s11056-005-7480-y

De la Barrera F, Barraza P, Favier P, Ruiz V, Quense J (2018). Megafires in Chile 2017: monitoring multiscale environmental impacts of burned ecosystems. Science of the Total Environment 637-638: 1526-1536. - doi: 10.1016/j.scitotenv.20 18.05.119

Del Campo AD, Navarro RM, Ceacero CJ (2010). Seedling quality and field performance of commercial stocklots of containerized holm oak (Quercus ilex) in Mediterranean Spain: an approach for establishing a quality standard. New Forest 39: 19-37. - doi: 10.1007/s11056-009-91529

Domínguez-Lerena S, Herrero N, Carrasco I, Ocaña L, Peñuelas JL, Mexal JG (2006). Container characteristics influence Pinus pinea seedlings development in the nursery and field. Forest Ecology and Management 221: 63-71. doi: 10.1016/j.foreco.2005.08.031

Espinoza S, Santelices R, Cabrera A, Magni C (2017). Interactive effects of water stress, container size and fertilizer on survival, gas exchange and morphological traits of Quillaja saponaria seedlings. Bosque 38 (2): 409-414. doi: $10.4067 /$ S0717-92002017000200018 Gibbens R, Lenz JM (2001). Root systems of 
some Chihuahuan desert plants. Journal of Arid Environments 49: 221-263. - doi: 10.1006/jare. 2000.0784

Giencke LM, Denhof RC, Kirkmann LK, Stubber OS, Brantley ST (2018). Seed sourcing for longleaf pine ground cover restoration: using plant performance to assess seed transfer zones and home-site advantage. Restoration Ecology 26 (6): 1127-1136. - doi: 10.1111/rec.12673 Giliberto J, Estay H (1978). Seasonal water stress in some chilean matorral shrubs. Botanical Gazette 139: 236-240. - doi: 10.1086/336995 Gratani L, Meneghini M, Pesoli P, Crescente MF (2003). Structural and functional plasticity of Quercus ilex seedlings of different provenances in Italy. Trees 17: 515-521. - doi: 10.1007/s00468003-0269-8

Grossnickle S (2005). Importance of root growth in overcoming planting stress. New Forests 30: 273-294. - doi: 10.1007/s11056-004-8303-2

Grossnickle SC (2012). Why seedlings survive: influence of plant attributes. New Forests 43: 711738. - doi: 10.1007/s11056-012-9336-6

Grossnickle SC, MacDonald JE (2018). Why seedlings grow: influence of plant attributes. New Forests 49: 1-34. - doi: 10.1007/s11056-017-96064

ISTA (2006). International rules for seed testing. International Seed Testing Association (ISTA). Bassersdorf, Switzerland.

Joshi J, Schmid B, Caldeira MC, Dimitrakopoulos PG, Good J, Harris R, Hector A, Huss-Danell K, Jumpponen A, Minns A, Mulder CPH, Pereira JS, Prinz A, Scherer-Lorenzen M, Siamantziouras ASD, Terry AC, Troumbis AY, Lawton JH (2001). Local adaptation enhances performance of common plant species. Ecological Letters 4: 536-544. - doi: 10.1046/j.1461-0248.20 01.00262.x

Leimu R, Fischer M (2008). A meta-analysis of local adaptation in plants. PLoS ONE 3: 1-8. - doi: 10.1371/journal.pone.0004010

Luis VC, Puértolas J, Climent J, Peters J, González-Rodríguez AM, Morales D, Jiménez MS (2009). Nursery fertilization enhances survival and physiological status in Canary Island pine (Pinus canariensis) seedlings planted in a semiarid environment. European Journal of Forest Research 128: 221-229. - doi: 10.1007/s10342-00 9-0257-7

Magni C, Espinoza S, Poch P, Abarca B, Grez I, Martínez E, Yáñez M, Santelices R, Cabrera A (2018). Growth and biomass partitioning of nine provenances of Quillaja saponaria seed- lings to water stress. Southern Forests 81 (2): 103-109. - doi: 10.2989/20702620.2018.1512789 Niinemets $U$, Valladares F (2004). Photosynthetic acclimation to simultaneous and interacting environmental stresses along natural light gradients: optimality and constraints. Plant Biology 6: 254-268. - doi: 10.1055/s-2004817881

Niklas KJ, Enquist BJ (2002). Canonical rules for plant organ biomass partitioning and annual allocation. American Journal of Botany 89 (5): 812-819. - doi: 10.3732/ajb.89.5.812

Ovalle JF, Arellano EC, Oliet JA JA, Becerra P, Ginocchio R (2016a). Linking nursery nutritional status and water availability post-planting under intense summer drought: the case of a South American Mediterranean tree species. iForest - Biogeosciences and Forestry 9: 758765. - doi: 10.3832/ifor1905-009

Ovalle JF, Arellano EC, Ginocchio R, Becerra P (2016b). Fertilizer location modifies root zone salinity, root morphology, and water stress resistance of tree seedlings according to the watering regime in a dryland reforestation. Journal of Plant Nutrition and Soil Science 179: 223233. - doi: 10.1002/jpln.201500181

Padilla FM, Pugnaire FI (2007). Rooting depth and soil moisture control Mediterranean woody seedling survival during drought. Functional Ecology 21: 489-495. - doi: 10.1111/j.13652435.2007.01267.x

Padilla F, Miranda J, Ortega R, Hervás M, Sánchez J, Pugnaire FI (2011). Does shelter enhance early seedling survival in dry environments? A test with eight Mediterranean species. Applied Vegetation Science 14: 31-39. - doi: 10.1111/j.1654109X.2010.01094.X

Palacios G, Navarro Cerrillo RM, Del Campo A, Toral M (2009). Site preparation, stock quality and planting date effect on early establishment of Holm oak (Quercus ilex L.) seedlings. Ecological Engineering 35: 38-46. - doi: 10.1016/j.ecole ng.2008.09.006

Poorter H, Bühler J, Van Dusschoten J, Climent J, Postma JA (2012). Pot size matters: a metaanalysis of the effects of rooting volume on plant growth. Functional Plant Biology 39: 839850. - doi: 10.1071/FP12049

Rey-Benayas JM (1998). Growth and mortality in Quercus ilex L. seedlings after irrigation and artificial shading in Mediterranean set-aside agricultural lands. Annals of Forest Science 55: 801807. - doi: 10.1051/forest:19980704

Richardson AD, Duigan SP, Berlyn GP (2002). An evaluation of noninvasive methods to estimate foliar chlorophyll content. New Phytologist 153: 185-194. - doi: 10.1046/j.0028-646X.2001.0028 9. $\mathrm{x}$

Seiler JR, Johnson JD (1988). Physiological and morphological responses of three half-sib families to water stress conditioning. Forest Science 34: 487-495. [online] URL: https://academic. oup.com/forestscience/article-abstract/34/2/48 7/4642465

Trubat R, Cortina J, Vilagrosa A (2010). Nursery fertilization affects seedling traits but not field performance in Quercus suber L. Journal of Arid Environments 74: 491-497. - doi: 10.1016/j.jaride nv.2009.10.007

Tsakaldimi M, Zagas T, Tsitsoni T, Ganatsas P (2005). Root morphology, stem growth and field performance of seedlings of two Mediterranean evergreen oak species raised in different container types. Plant and Soil 278: 85-73. doi: 10.1007/s11104-005-2580-1

Tsakaldimi M, Ganastas P, Jacobs DF (2013). Prediction of planted seedling survival of five Mediterranean species based on initial seedling morphology. New Forests 44: 327-339. - doi: 10.1007/s11056-012-9339-3

Valladares F, Balaguer L, Martínez-Ferri E, PérezCorona E, Manrique E (2002a). Plasticity, instability and canalization: is the phenotypic variation in seedlings of sclerophyll oaks consistent with the environmental unpredictability of Mediterranean ecosystems? New Phytologist 156: 457-467. - doi: 10.1046/j.1469-8137.2002.005 25. $x$

Valladares F, Chico JM, Aranda I, Balaguer L, Dizengremel P, Manrique E, Dreyer D (2002b). Greater high light seedling tolerance of Quercus robur over Fagus sylvatica is linked to a greater physiological plasticity. Trees 16: 395403. - doi: 10.1007/s00468-002-0184-4

Van Der Mijnsbrugge K, Bischoff A, Smith B (2010). A question of origin: where and how to collect seed for ecological restoration. Basic and Applied Ecology 11: 300-311. - doi: 10.1016/j. baae.2009.09.002

Villar-Salvador P, Puértolas J, Cuesta B, Peñuelas $J$, Uscola M, Heredia-Guerrero N, Rey Benayas JM (2012). Increase in size and nitrogen concentration enhances seedling survival in Mediterranean plantations. Insights from an ecophysiological conceptual model of plant survival. New Forests 43: 755-770. - doi: 10.1007/s11056-0129328-6 